\title{
VARIABILITY OF NUTRIENTS IN THE LEACHATES FROM EVERBEARING STRAWBERRY CULTIVATED IN SOILLESS CONDITIONS ON GUTTERS
}

\author{
Michał Kopeć ${ }^{1 凶}$, Monika Mierzwa-Hersztek ${ }^{1}$, Krzysztof Gondek ${ }^{1}$, Tomasz Zaleski², \\ Stanisław Bogdał , Monika Bieniasz $z^{4}$ Jan Błaszczyk ${ }^{4}$ Elżbieta Kaczmarczyk \\ Jarosław Knaga ${ }^{5}$, Bogusława Łapczyńka-Kordon ${ }^{6}$, Jacek Nawrocki , Michał Pniak ${ }^{8}$ \\ ${ }^{1}$ Department of Agricultural and Environmental Chemistry, University of Agriculture in Krakow, al. Mickiewicza 21, 31-120 Kraków \\ 2 Department of Soil Science and Agrophysics, University of Agriculture in Krakow, al. Mickiewicza 21, 31-120 Kraków \\ 3 Stanflex-Polski Instytut Truskawki Sp.zo.o., ul. L. Petrażyckiego 20/1, 30-399 Kraków \\ ${ }^{4}$ Department of Horticulture, University of Agriculture in Krakow, al. 29 Listopada 54, 31-425 Kraków \\ ${ }^{5}$ Department of Bioprocess Engineering, Power Engineering and Automation, University of Agriculture in Krakow, \\ ul. Balicka 116 b, 30-149 Kraków \\ ${ }^{6}$ Department of Mechanical Engineering and Agrophysics, University of Agriculture in Krakow, ul. Balicka 120, 30-149 Kraków \\ 7 Department of Botany, Plant Physiology and Protection, University of Agriculture in Krakow, al. 29 Listopada 54, 31-425 Kraków \\ ${ }^{8}$ BIOCONT Polska, al. 29 Listopada 56a, 31-425 Kraków
}

\begin{abstract}
\section{Aim of the study}

Industrial soilless cultivation of plants is associated with the formation of leachate, which may pose a threat to the environment. Their management is an important issue due to the limitation of the dissipation of ingredients in the environment, but also with the view to limiting the use of water, which in this type of cultivation is key not only in terms of quantity but also quality.
\end{abstract}

\begin{abstract}
Material and methods
The variability of nutrients in the leachates was analysed for everbearing strawberry of San Andreas variety cultivated in soilless conditions on gutters.

\section{Results and conclusions}

The chemical composition of leachates was characterized by a high dynamics of changes in the content of elements (nutrients) during the growing season. These changes are caused by the amount of nutrients given in the nutrient solution, and the frequency of fertigation due to transpiration and the amount of plant biomass conditioning the amount of components consumed. The chemical composition of the leachates from the strawberry plantation does not preclude their re-use in the recovery process.
\end{abstract}

Keywords: nutrients, leachate, everbearing strawberry

\section{INTRODUCTION}

The development of technology and the need for environmental protection as well as economic conditions are conducive to the introduction of a circular economy. One of the important areas that implements closed-loop systems is agriculture. The diversification of agriculture intensification results in a greater or lesser degree of dispersion of nutrients in the environment. This produces a situation in which some of

®e-mail: michal.kopec@urk.edu.pl 
the nutrients, such as phosphorus, become of critical importance and, on the other hand, they threaten the environment by causing, e.g. eutrophication of water bodies. Control systems for the dispersion of nutrients are increasingly being proposed. This is possible primarily in gardening and closed-loop greenhouse systems. Extreme solutions include controlled crops dedicated to astronauts or urban vertical farms (Furfaro et al. 2016, Burchi et al. 2018). In these cases, it is assumed that maximum circulation of components must be achieved. Aquaculture cultivation or fertigation of soilless crops require controlling the environment in which the plant root system is maintained. Under these conditions, it is also possible to prevent a certain amount of leachate by observing technological parameters (Żarnowiec et al., 2014). In addition to physiological problems resulting from its own chemical composition, leachate also produces phytopathological problems, which is particularly important in crops grown under cover (Meric et al., 2011). Under such conditions, as a result of the necessary air exchange, there is a risk of the crop being exposed to vectors transmitting disease from the outside. Diseases can also appear as a result of infected planting material, less often seeds or soil.

Leachate recovery systems, which protect the environment against topical (point and area) pollution, must take into account a number of parameters that allow achieving the desired production outcome. In many countries, the legal issue of leachate from greenhouse cultivation has still not been resolved (Breś and Trelka, 2015). In Polish conditions, the possibility of recovery using the R10 method (Journal of Laws... 2015.132.) is provided for this type of waste, defined as leachate media from hydroponics. This particular waste, assigned the code ex 020183 , is classified as mineral waste and it can be introduced into the environment provided that a number of specific conditions are met all at once, pertaining to the acceptable dose of waste, soil richness, land use, waste quality, and plant demand for nutrients, as well as principles of good agricultural practice. The waste holder must be able to produce the results of tests confirming the quality of waste and the quality of soil on which the waste is to be used. Their interpretation, due to the large number of variables, must be based on agronomic knowledge in the field of agricultural chemistry.
For leachate holders, the cost-generating problems arising from these provisions include primarily the need to collect samples as well as carry out the tests of the leachate, and of the soil into which this type of material could be introduced. In the case of tests, their scope has not been specified; only a general reference is made to the principles of good agricultural practice. On the one hand, the forms of ingredients used in fertilizing greenhouse crops are readily available to plants, which means that plants can absorb them relatively quickly. On the other hand, in certain weather conditions (e.g. excessive rainfall) there is a risk of their leaching beyond the reach of the plant root system - this particularly concerns those components that are not retained by the solid phase of the soil, for instance, nitrates. In view of the need to comply with the principles of good agricultural practice, the use of leachate outside the period of growth of plants intended for direct consumption is also a limiting provision, however justified.

The introduction of leachate to the soil is a relatively simple procedure. Nevertheless, this treatment may require that the farmer possesses specialized equipment, enabling the application of this type of material under the soil surface of the soil. Other applications, for instance, closed circulation of ingredients in cultivation, often require hygienisation processes, and balancing the chemical composition in terms of quantity and relative share of the nutrients (Meric et al., 2011). For the purposes of hygienisation and standardization (Hosseinzadeh et al., 2017), the studied aspects included the impact of activated carbon, the process of ozonisation, and the use of ion exchange resin in the removal of organic compounds from the reused nutrient solution. It has been shown that the use of activated carbon can remove more organic compounds than other treatments. Activated carbon application can be a highly efficient technique associated with the removal of root secretions, while, at the same time, the concentration of inorganic ions as nutrients remains unchanged.

Despite the problems in the field of nutrient management, it seems justified to recover them by returning the hygienised medium to plant production processes (Neocleous and Savvas, 2016). Directions of research pertaining to the use of ingredients include the development of models of plant tolerance to environmental 
conditions, e.g. based on salinity of the solution (Sabat et al., 2015; Neocleous and Savvas, 2016).

Additional factors for uncertainty of medium recovery are related to the period of use of the substrate. Usually, along with the length of the cultivation period, the physicochemical properties of the substrate deteriorate, manifested by increased bulk density, reduced porosity, and leaching of nutrients, their lack of balance (Song et al., 2013), as well as reduced enzyme activity in the substrate (Yang and Li, 2013).

Considering the possibility of reusing the post-usage nutrient media, one more important aspect should be noted; namely, limiting the reduction of water consumption. In this type of crop, the latter is a key element not only in quantitative but also qualitative terms.

The aim of the present study was to determine the variability of the chemical composition of ash elements in the leachate, during the growing season of everbearing strawberry carried out in soilless conditions, in terms of the feasibility of their reuse in fertigation, i.e. the implementation of closed circulation of ingredients. Reliability and significance of present research follows from the scale of production, and refers to the cultivation method introduced in practice only recently, that is, within the last few years.

\section{MATERIALAND METHODS}

The research was carried out on the experimental plantation of the Stanflex - Polski Instytut Truskawki sp. z o.o. (Stanflex - Polish Strawberry Institute, limited company), located in Tyniec near Kraków, in a place with geographical coordinates $50^{\circ} 02^{\prime} 11^{\prime \prime} \mathrm{N}$ and $19^{\circ} 81^{\prime} 19^{\prime \prime} \mathrm{E}$. The 4-hectare plantation everbearing strawberry (i.e. one with repeated fruiting), was carried out in a gutter system under roofing, on a soilless substrate, i.e. in mats with a coconut medium in white foil measuring $1000 \mathrm{~mm} \times 200 \mathrm{~mm} \times 100 \mathrm{~mm}$ (see: Fig. 1). Before planting the strawberries, mat buffering was carried out using a solution of calcium nitrate $\left(\mathrm{pH}=5.5, \mathrm{EC}=1,2-1,7 \mathrm{mS} \cdot \mathrm{cm}^{-1}\right)$. Strawberry seedlings (Fragaria $\times$ ananassa Duch) of the San Andreas ${ }^{\circledR}$ variety were planted on 13 June 2018 . The crop was annual. After the growing season, the crop was liquidated due to the risk of its not surviving the winter cropping, and the possible threat from pathogens.

Six overflow stations were installed on the plantation, i.e. places where, regardless the change of the gutter angle, it was possible to collect leachate over a 4-metre section with holes, as well as monitor their volume and chemical composition. In order to examine the chemical composition of the leachate, samples

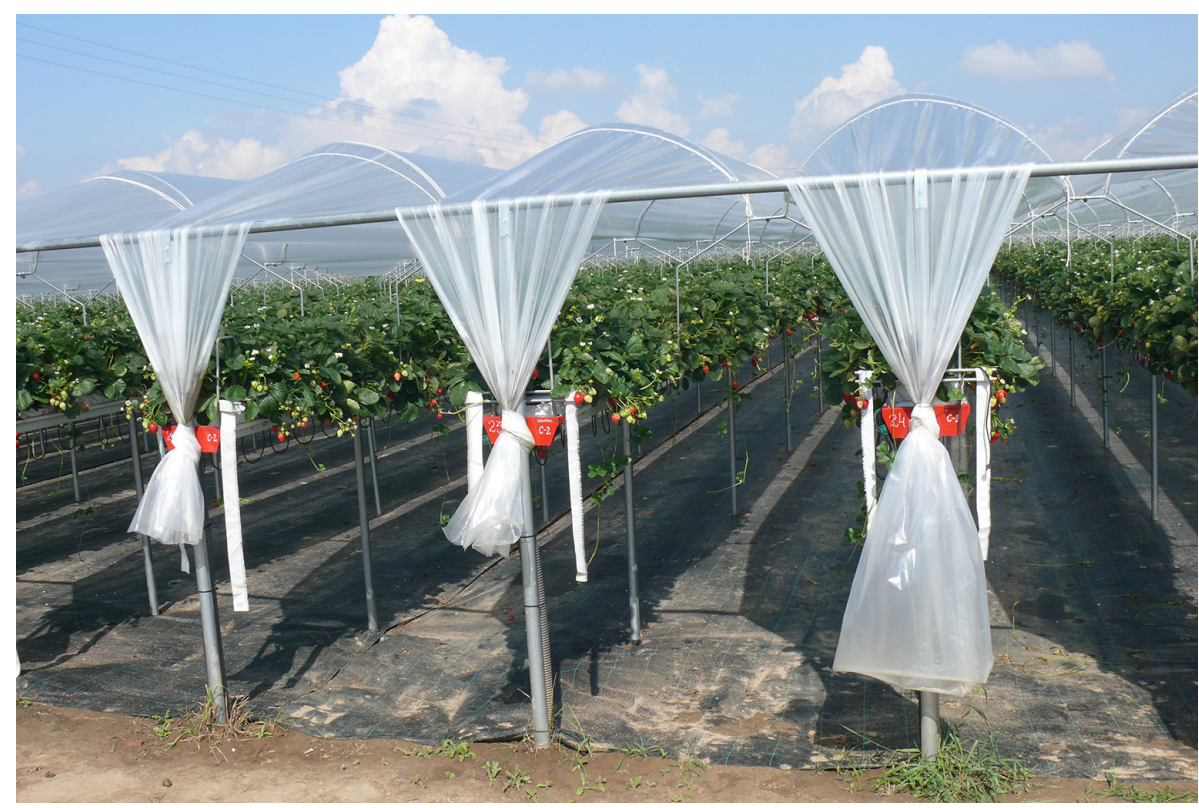

Fig. 1. Plantation of everbearing strawberry 
were collected from June 11 to November 9, 2018, at 21 dates, every 7 to 10 days.

During the vegetation, fertilizers were used in the following doses (per running meter of the mat): calcium nitrate $-156.8 \mathrm{~g}$; ammonium nitrate $-3.587 \mathrm{~g}$; magnesium nitrate - 34.97; DTPA iron chelate 7\% $\mathrm{Fe}-2.130 \mathrm{~g}$; EDDHA iron chelate $6 \% \mathrm{Fe}-2.461 \mathrm{~g}$; monopotassium phosphate $-22.51 \mathrm{~g}$; potassium nitrate $-34.26 \mathrm{~g}$; magnesium sulphate - $17.70 \mathrm{~g}$; manganese sulphate $-0.760 \mathrm{~g} ; 13 \%$ EDTA manganese chelate $-1.875 \mathrm{~g}$; zinc sulphate $-0.334 \mathrm{~g}$; copper sulphate $-0.067 \mathrm{~g}$; borax $-0.103 \mathrm{~g}$; sodium molybdate $-0.021 \mathrm{~g}$; and nitric acid $-86.92 \mathrm{~g}$.

2018 in the area where the experiment was conducted was a dry and hot year. Maximum air temperatures measured under the gutter (at a height of $1 \mathrm{~m}$ above the ground) were recorded in August, and they reached $44^{\circ} \mathrm{C}$, with an average daily value at the beginning of August at $26.0^{\circ} \mathrm{C}$. The average relative humidity values increased with time, and in late autumn they exceeded $90 \%$ (see: Fig. 2). The average values presented in the figure were calculated from the values obtained in 10-minute cycles over 18 days.

Leachate samples taken at the plantation were cooled to about $4^{\circ} \mathrm{C}$, and immediately transported to the laboratory. The activity of hydrogen ions $(\mathrm{pH})$ was de- termined electrochemically ( $\mathrm{pH}$ meter CP-505), while the electrolytic conductivity (EC) was determined via conductometry (CPC-502 conductivity meter) while maintaining the ration of material to water $=1: 5$. In order to determine the content of ash nutrients, leachate sample were mixed (effluent: acid ratio at 1:10) with diluted $(1: 2)$ nitric acid. The solutions prepared in this way were tested for selected nutrients, applying the ICP-OES method, on a PerkinElmer Optima 7100 DV Inc. (Kaya and Ashraf 2018). Chemical composition analyses were performed in the laboratory of the Department of Agricultural and Environmental Chemistry of the University of Agriculture in Kraków.

The measure of dispersion was classified according to the ranges proposed by Baryshev: the coefficient of variation (V) up to $20 \%$ signifies low (M) variability; $20-40 \%$ signifies average variability $(\mathrm{P})$, $40-100 \%$ signifies high variability (D), $100-150 \%$ signifies very high variability (BD), and over $150 \%$, extremely high (SD).

$$
\mathrm{V}=\mathrm{SD} \cdot 100 / \mathrm{x}[\%]
$$

where:

SD - standard deviation,

$\mathrm{x}-$ mean value.

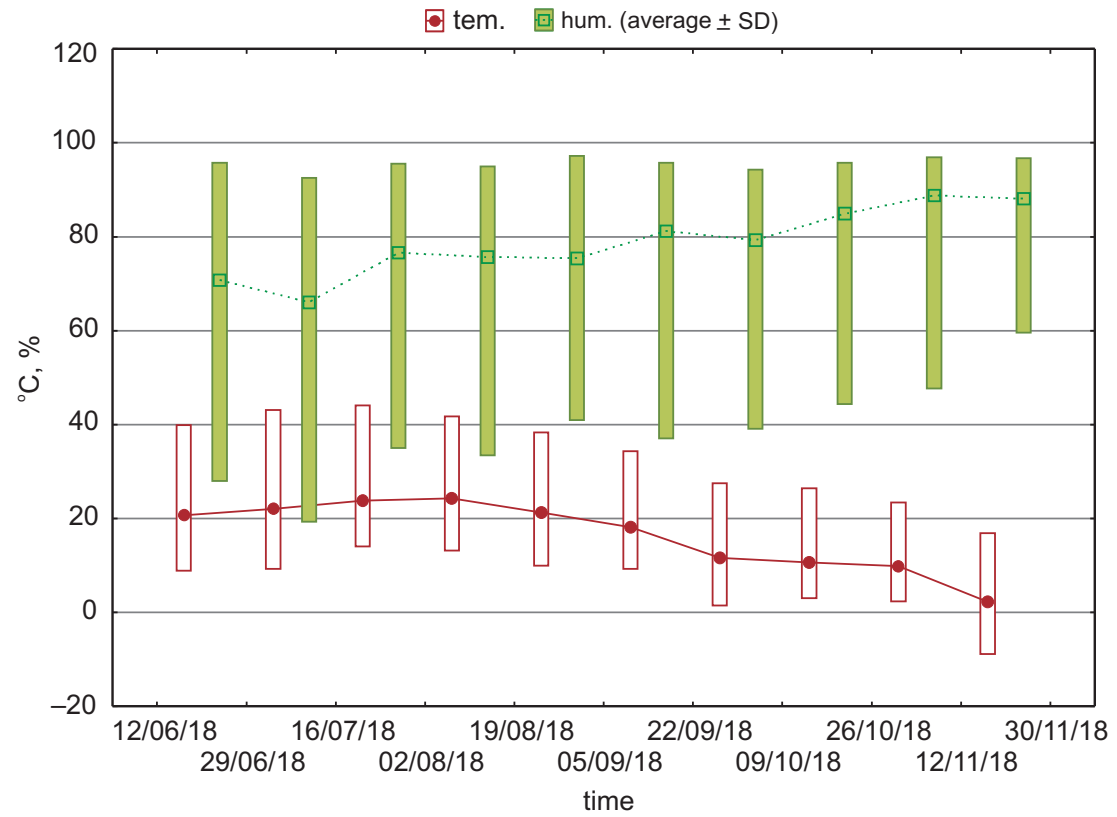

Fig. 2. Temperature values and air humidity during the growing season 


\section{RESULTS AND DISCUSSION}

Variability of the content of elements in the leachate during the growing season of strawberries (i.e. in 24 th 48 th week of the year) was determined by the variability of the chemical composition of the substrate. The chemical composition of the substrate was modified depending on the plant development phase, possible symptoms of component deficiency, as well as weather conditions (temperature, sunlight) affecting the intensity of transpiration (see: Fig. 2). However, these factors were decisive to varying degrees with respect to individual elements. This is due to the fact of introducing and withdrawing elements from the nutrient medium, depending on the vegetation phases and the nutritional status of the plants. In addition to mat buffering, the initial period was based on starter substrate, and then on fruit substrate. During the growing season of plants, the amounts of absorbed nutrients differ (Kopeć et al., 2019). As demonstrated in the research of Sabat et al. (2019), with an increase in $\mathrm{EC}$ value resulting from an increase in salt concentration, the content of $\mathrm{P}$ and $\mathrm{K}$ in lettuce leaves increased significantly, while the content of $\mathrm{Ca}$ and $\mathrm{Mg}$ did not change much. This was dictated, among others, by the chemistry of the physiology of the collection of individual elements, as a consequence of competition for conveyors in semipermeable membranes. It was also found that the type of substrate had a significant impact on the content of $\mathrm{K}, \mathrm{P}, \mathrm{Ca}$, and $\mathrm{Mg}$ in lettuce leaves. The highest content of these ingredients was found in lettuce grown on a coconut substrate, and the smallest on a peat substrate, which was due to the ability of the substrates to sorb individual elements. This resulted in a diverse content of ingredients in the draining medium, and thus had an impact on the balance of ingredients.

In our research, the highest contents in the leachate from the growing season (average) as well as at the end of the growing season in the leachate tank concerned $\mathrm{Ca}, \mathrm{K}$, and $\mathrm{Na}$. Changes in the content of $\mathrm{Ca}$ and $\mathrm{K}$ result from the fact that these elements are balanced into macronutrients in the medium (see: Table 1). The high $\mathrm{Na}$ content, and the value of the coefficient of variation of the content of this element were both caused by the frequently changing $\mathrm{Na}$ content in the water taken from shallow intakes (wells). Hydrogeological conditions in this respect did not make these wells useful sources of water for fertigation. The measure of dis- persion of the content of individual elements during the growing season in leachate was generally high and very high. Particularly noteworthy is the variability of phosphorus content, which is an important nutrient. Very high variations in the manganese and molybdenum content are probably due to precipitation processes. A measure of variation indicating high dispersion of element content is important information in the context of leachate recovery, as the risk pertaining to their use thus increases. A safer solution is to collect leachate and use it from a larger volume, characterized by greater uniformity of elements' content.

Table 1 presents the fertilizing potential of introducing nutrients with a possible dose of $10 \mathrm{~m}^{3}$. The use of this amount of leachate per hectare of any crop does not pose a risk in the context of ash components. These are the values of the ingredients well below the standard doses of the ingredients in fertilizers (Jadczyszyn et al., 2010). A slight risk to the environment for this particular leachate may be salinity in the event of repeated application treatment.

The data presented in Figures 3-7 represent high variability in the content of individual components resulting probably primarily from their uptake by plants (Kopeć et al., 2019). In late autumn, increased concentration of elements was found in leachate, which was probably due to lower uptake resulting from lower fruit yield and inhibition of vegetative biomass growth (see: Fig. 8). This reasoning is also confirmed by the concentrations of some elements after the transition from starter medium to fertigation with fruit medium.

The issue of leachate application from closed crops will be particularly intensively studied in the near future. This is due to the introduction of soilless cultivation technology and technical management capabilities, including process automation. By using leachate recirculation, it is possible to reduce water consumption by $15-35 \%$, and to reduce the loss of components in the medium by $15-67 \%$ (Meric et al., 2011). However, the commercial application of these systems is limited, because it requires higher management expenditure. From the point of view of environmental protection, sustainable development, and water resource management, closed systems and relatively infrequent irrigation are feasible for practical application, with an acceptable-level risk of a decrease in crop efficiency (Meric et al., 2011). 
Kopeć, M., Mierzwa-Hersztek, M., Gondek, K.,Zaleski,T., Bogdał, S., Bieniasz, M., Błaszczyk,J., Knaga, J., Nawrocki,J., Pniak, M. (2019).Variability of nutrients in the leachates... Acta Sci. Pol., Formatio Circumiectus, 18 (4), 13-23. DOI: http://dx.doi.org/10.15576/ASP.FC/2019.18.4.13

Table 1. Average (from the growing season) chemical composition of leachates from strawberry soilless culture and onetime determination of the chemical composition in the leachate tank in November, with the conversion of the component dose into $10 \mathrm{~m}^{3}$ of leachate

\begin{tabular}{ccccccc}
\hline \multirow{2}{*}{ Parameter } & \multirow{2}{*}{ Unit } & \multicolumn{3}{c}{ Growing season } & Container & Fertilizer potential \\
\cline { 3 - 6 } & & mean & $\mathrm{SD}^{2}$ & $\mathrm{~V}^{3}[\%]$ & $\mathrm{g} \cdot 10 \mathrm{~m}^{-3}$ \\
\hline $\mathrm{nH}$ & $\mathrm{mS} \cdot \mathrm{cm}^{-1}$ & 2.619 & 0.662 & $25.3 \mathrm{P}^{* 4}$ & 3.49 & - \\
\hline $\mathrm{EC}$ & $\mathrm{mg} \cdot \mathrm{dm}^{-3}$ & 0.168 & 0.071 & $42.5 \mathrm{D}$ & 0.138 & 1.38 \\
\hline $\mathrm{B}$ & $\mathrm{mg} \cdot \mathrm{dm}^{-3}$ & 172.49 & 66.54 & $38.5 \mathrm{P}$ & 164.3 & 1643 \\
\hline $\mathrm{Ca}$ & $\mathrm{mg} \cdot \mathrm{dm}^{-3}$ & 0.115 & 0.085 & $73.9 \mathrm{D}$ & 0.157 & 1.57 \\
\hline $\mathrm{Cu}$ & $\mathrm{mg} \cdot \mathrm{dm}^{-3}$ & 1.085 & 0.546 & $50.3 \mathrm{D}$ & 1.073 & 10.7 \\
\hline $\mathrm{Fe}$ & $\mathrm{mg} \cdot \mathrm{dm}^{-3}$ & 134.36 & 90.07 & $67.0 \mathrm{D}$ & 132.85 & 1328 \\
\hline $\mathrm{K}$ & $\mathrm{mg} \cdot \mathrm{dm}^{-3}$ & 0.0140 & 0.0076 & $54.0 \mathrm{D}$ & 0.025 & 0.02 \\
\hline $\mathrm{Li}$ & $\mathrm{mg} \cdot \mathrm{dm}^{-3}$ & 55.71 & 32.53 & $58.4 \mathrm{D}$ & 68.485 & 684.8 \\
\hline $\mathrm{Mg}$ & $\mathrm{mg} \cdot \mathrm{dm}^{-3}$ & 1.232 & 1.385 & $112.4 \mathrm{BD}$ & 0.267 & 2.67 \\
\hline $\mathrm{Mn}$ & $\mathrm{mg} \cdot \mathrm{dm}^{-3}$ & 0.002 & 0.003 & $150.0 \mathrm{BD}$ & 0.002 & 0.002 \\
\hline $\mathrm{Mo}$ & $\mathrm{mg} \cdot \mathrm{dm}^{-3}$ & 224.3 & 152.0 & $67.9 \mathrm{D}$ & 329.75 & 3297 \\
\hline $\mathrm{Na}$ & $\mathrm{mg} \cdot \mathrm{dm}^{-3}$ & 12.24 & 14.28 & $116.7 \mathrm{BD}$ & 8.63 & 86.4 \\
\hline $\mathrm{P}$ & $\mathrm{mg} \cdot \mathrm{dm}^{-3}$ & 3.490 & 1.989 & $57.0 \mathrm{D}$ & 1.579 & 15.8 \\
\hline $\mathrm{Si}$ & $\mathrm{mg} \cdot \mathrm{dm}^{-3}$ & 1.058 & 0.794 & $75.0 \mathrm{D}$ & 1.860 & 18.6 \\
\hline $\mathrm{Zn}$ & & & & & \\
\hline
\end{tabular}

1) EC - electrolytic conductivity

2) $\mathrm{SD}$ - standard deviation

3) $\mathrm{V}$ - coefficient of variation

4) classes of variation as in the methodology

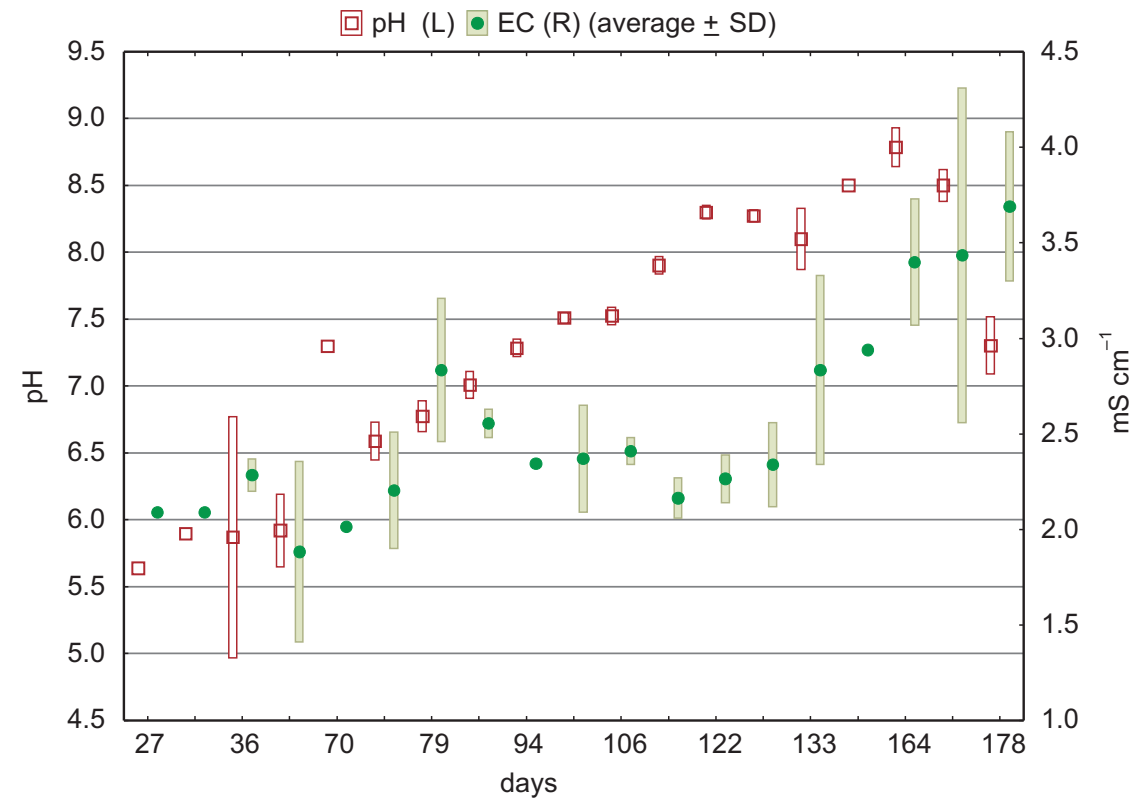

Fig. 3. Variability of $\mathrm{pH}$ and $\mathrm{EC}$ in the leachate during the growing season 


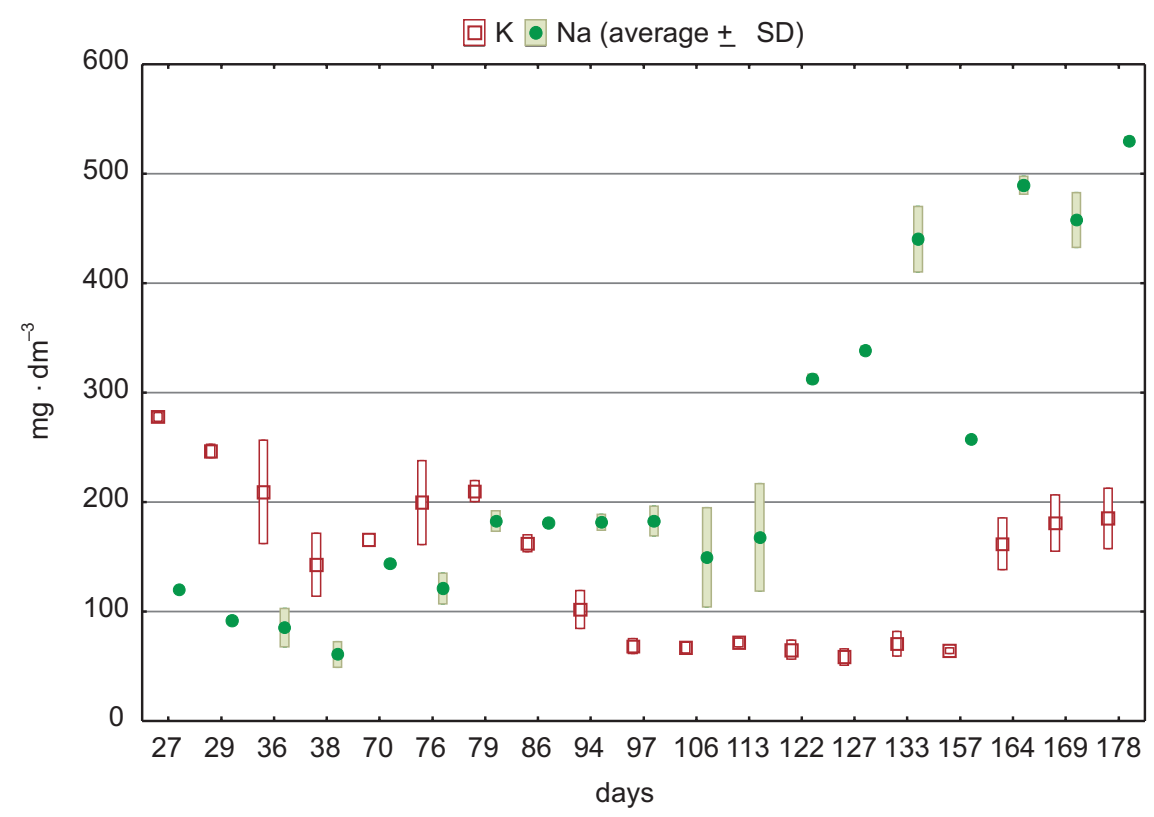

Fig. 4. Variability of $\mathrm{K}$ and $\mathrm{Na}$ content in the leachate during the growing season

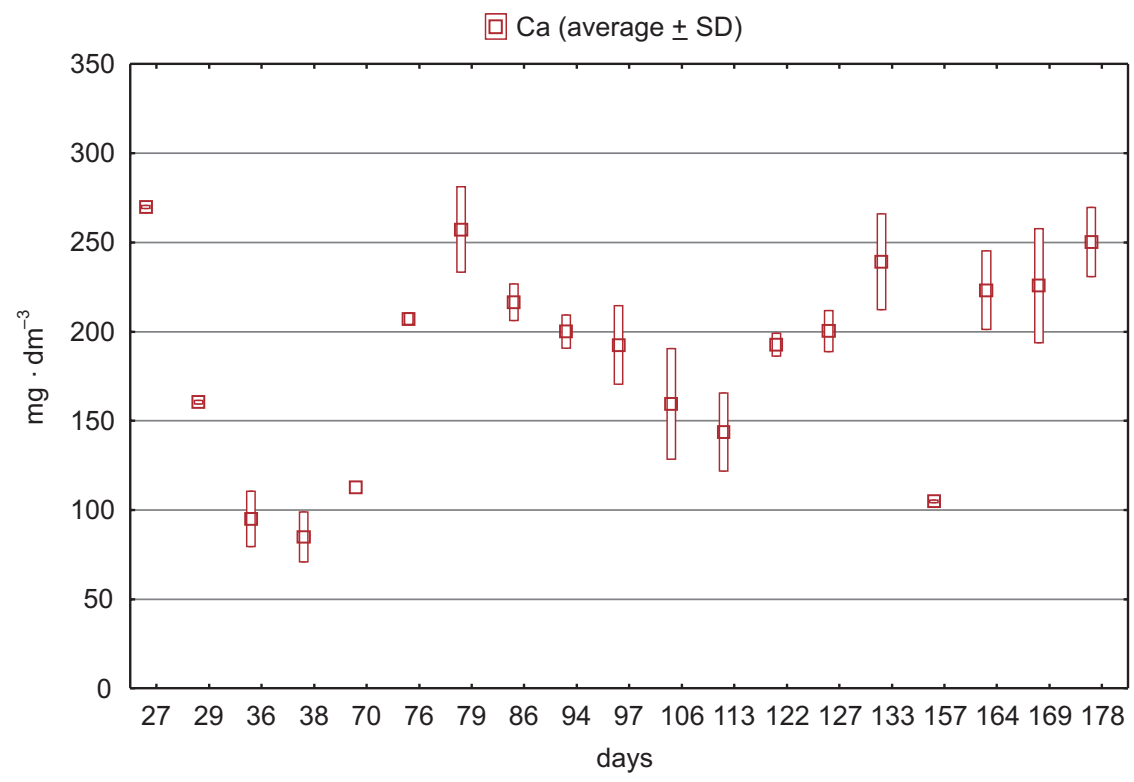

Fig. 5. Variability of Ca content in the leachate during the growing season 
Kopeć, M., Mierzwa-Hersztek, M., Gondek, K., Zaleski, T., Bogdał, S., Bieniasz, M., Błaszczyk, J., Knaga, J., Nawrocki, J., Pniak, M. (2019). Variability of nutrients in the leachates... Acta Sci. Pol., Formatio Circumiectus, 18 (4), 13-23. DOI:

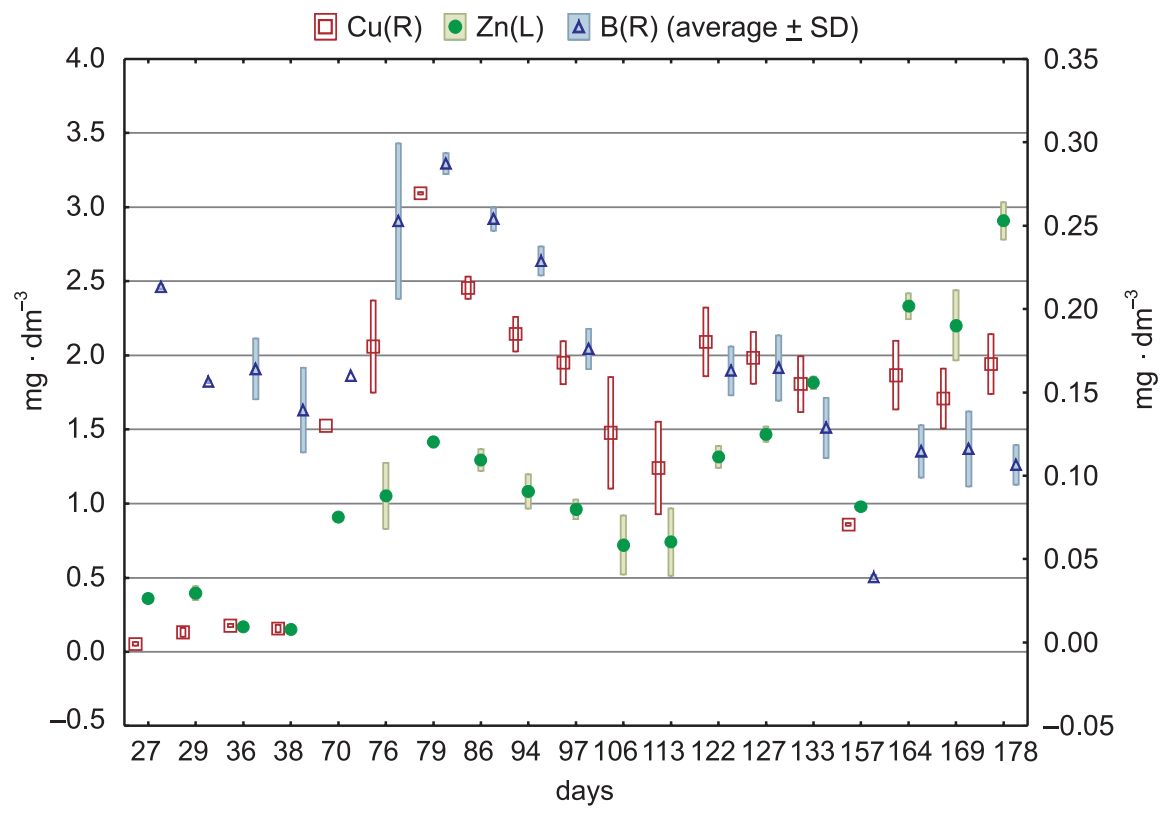

Fig. 6. Variability of $\mathrm{Cu}, \mathrm{Zn}$ and $\mathrm{B}$ content in leachate during the growing season

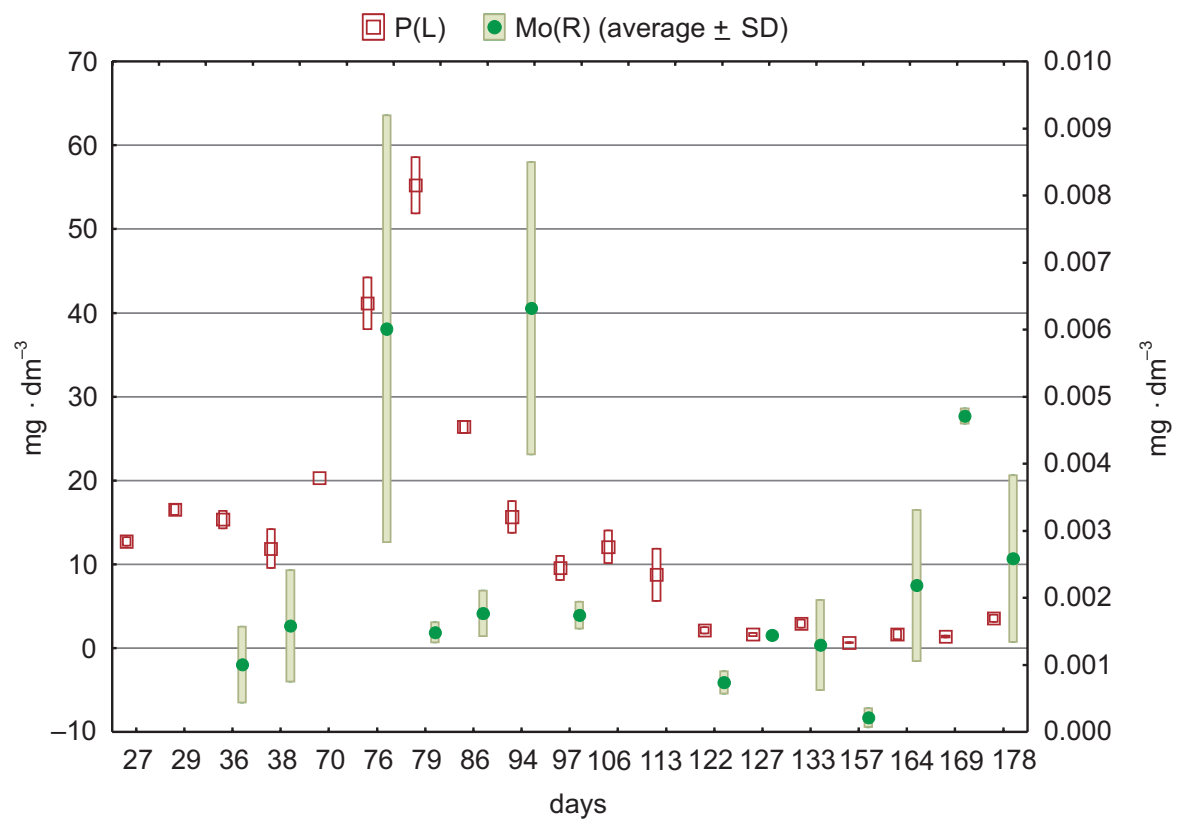

Fig. 7. Variability of $\mathrm{P}$ and Mo content in leachate during the growing season 


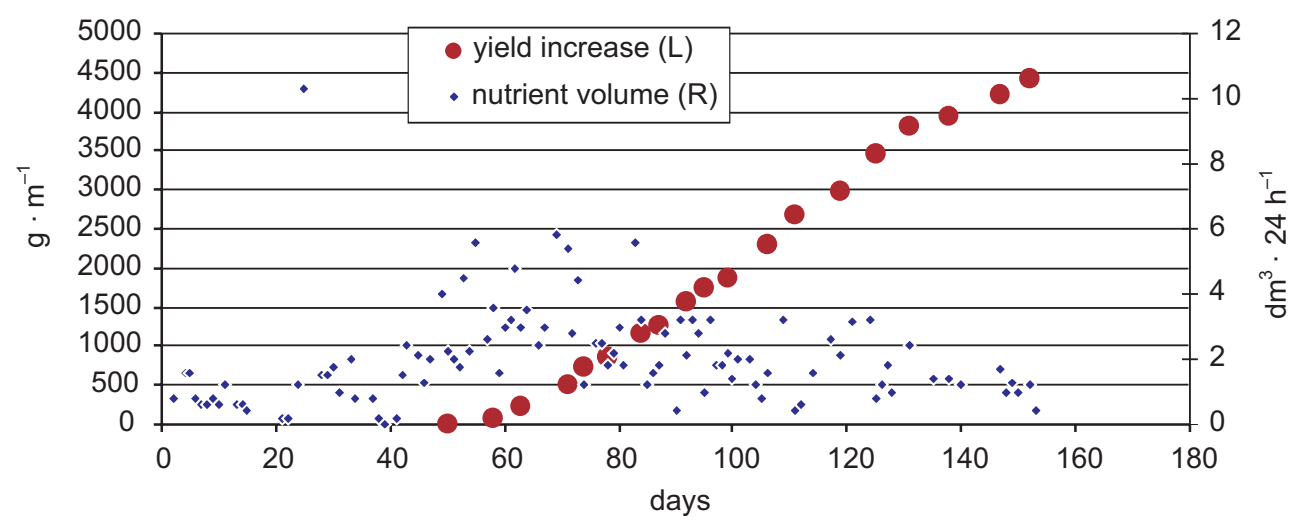

Fig. 8. Yield increase of strawberry fruit and nutrient volume during the growing season

Breś and Trelka (2015) state that since 2000, in the Netherlands, closed systems should be used or nutrient solution recovery should be carried out to reduce pollution, in particular in the context of surface water pollution, which is confirmed by research by Dyśko et al. (2013). In Mediterranean countries, the leachate from soilless cultivation systems is being treated as industrial waste. Great importance is attached to the maximum efficiency of water consumption in areas threatened by nitrate pollution. Leachate can also be used in biological processes of biomass transformation (composting) in the initial and final stages of the process where it is necessary to supplement water losses. The use of leachate is widespread, including for the production of strawberries (Vandecasteele et al., 2018).

The possibility of using soil-plant treatment facilities for leachate management has not yet been identified (Jóźwiakowski, 2012), because the amount of lost components (Chen and Wei, 2018) is a function of the type of fertilizer, time, substrate, filtration rate, micropore flow, root density, soil moisture content, as well as speed and intensity of irrigation. Due to all these factors, the problem is one of a high degree of complexity, requiring a multi-stage purification and many years of analysis of the effectiveness of the installation.

\section{CONCLUSIONS}

Leachate obtained from the soilless cultivation of everbearing strawberry in the gutter system is characterized by relatively high dynamics and a large variation in the content of elements (ash nutrients) during the growing season. These changes are caused by the amount of ingredients administered in the medium, and the frequency of fertigation, conditioned probably by the transpiration and the amount of the absorbed ingredients, with an increase in the biomass (including the yield) of plants.

The chemical composition of the leachate from strawberry plantation does not preclude its reuse in the recovery and recycling process.

\section{ACKNOWLEDGEMENTS}

The research was financed as part of the project No. RPMP.01.02.01-12-0430/16 entitled "Development of an optimal, innovative model of growing everbearing strawberry, grown in modern gutter systems under roofs, based on soilless substrate."

The research was financed by the Ministry of Science and Higher Education.

\section{REFERENCES}

Breś, W., Trelka, T. (2015). Effect of fertigation on soil pollution during greenhouse plant cultivation/Wpływ fertygacji na zanieczyszczenie gleb podczas uprawy roślin w obiektach szklarniowych. Archives of Environmental Protection, 41(2), 75-81.

Burchi, G., Chessa, S., Gambineri, F., Kocian, A., Massa, D., Milazzo, P., Rimediotti, L., Ruggeri, A. (2018). Information technology controlled greenhouse: A system architecture. In: IoT Vertical and Topical Summit on Agriculture-Tuscany (IOT Tuscany), (pp. 1-6). IEEE. 
Chen, J., Wei, X. (2018). Controlled-Release Fertilizers as a Means to Reduce Nitrogen Leaching and Runoff in Container-Grown Plant Production. Nitrogen in Agriculture, Updates, 33

Dyśko, J., Kaniszewski, S., Kowalczyk, W. (2013). Wpływ bezglebowych upraw szklarniowych na zanieczyszczenie płytkich wód gruntowych odciekami nawozowymi. Infrastruktura i Ekologia Terenów Wiejskich, (2/I).

Journal of Laws of the Republic of Poland 2015.132. Rozporządzenie Ministra Środowiska z dnia 20 stycznia 2015 r. w sprawie procesu odzysku R10.

Furfaro, R., Sadler, P., Giacomelli, G. (2016). Mars-lunar greenhouse (M-LGH) prototype for bioregenerative life support systems in future planetary outposts. In: Proceedings of the International Astronautical Congress, IAC. International Astronautical Federation, IAF.

Hosseinzadeh, S., Bonarrigo, G., Verheust, Y., Roccaro, P., Van Hulle, S. (2017). Water reuse in closed hydroponic systems: Comparison of GAC adsorption, ion exchange and ozonation processes to treat recycled nutrient solution. Aquacultural Engineering, 78, 190-195.

Jóźwiakowski, K. (2012). Badania skuteczności oczyszczania ścieków w wybranych systemach gruntowo-roślinnych. Infrastruktura i Ekologia Terenów Wiejskich, (1), 333.

Kopeć, M., Gondek, K., Mierzwa-Hersztek, M., Zaleski, T., Bogdał, S., Bieniasz, M., Błaszczyk J., Knaga, J., Kaczmarczyk, E., Pniak, M., Pałczyńska Kordon, E., Nawrocki, J. (2019). The effect of stimulating biomass growth of everbearing strawberry variety San Andreas ${ }^{\circledR}$ by the foliage application of a product containing zinc. Progress in Plant Protection, 59(2), $126-132$.
Meric, M. K., Tuzel, I. H., Tuzel, Y., Oztekin, G. B. (2011). Effects of nutrition systems and irrigation programs on tomato in soilless culture. Agricultural Water Management, 99(1), 19-25.

Jadczyszyn, T., Kowalczyk, J., Lipiński, W. (2010). Zalecenia nawozowe dla roślin uprawy polowej i trwałych użytków zielonych. Instytut Uprawy Nawożenia i Gleboznawstwa. Państwowy Instytut Badawczy.

Neocleous, D., Savvas, D. (2016). NaCl accumulation and macronutrient uptake by a melon crop in a closed hydroponic system in relation to water uptake. Agricultural Water Management, 165, 22-32.

Sabat, T., Kaniszewski, S., Dyśko, J. (2015). Effect of flood fertigation on yield of greenhouse lettuce grown in different substrates. Journal of Elementology, 20(2), 407-416.

Sabat, T., Kaniszewski, S., Dyśko, J. (2019). Flood fertigation of leaf lettuce grown in various substrates. Journal of Elementology, 24(1), 19-29.

Song, W.J., He, C.X., Yu, X.C., Zhang, Z.B., Li, Y.S., Yan, Y. (2013). Changes of organic soil substrate properties with different cultivation years and their effects on cucumber growth in solar greenhouse. Chinese J. Appl. Ecol. 24, 2857-2862.

Vandecasteele, B., Debode, J., Willekens, K., Van Delm, T. (2018). Recycling of $\mathrm{P}$ and $\mathrm{K}$ in circular horticulture through compost application in sustainable growing media for fertigated strawberry cultivation. European Journal of Agronomy, 96, 131-145.

Yang, Q., Li, L. (2013). Effects of planting years of vegetable solar greenhouse on soil microbial flora and enzyme activities. Chinese J. Appl. Ecol. 24, 2539-2544.

Żarnowiec, W., Bogdał, A., Rajda, W. (2014). Losses of water and nutrients in drip irrigation system of greenhouse cultivation. Acta Scientiarum Polonorum. Formatio Circumiectus, 13(4), 289-299.

\section{ZMIENNOŚĆ SKŁADNIKÓW POKARMOWYCH W ODCIEKACH Z UPRAWY TRUSKAWKI POWTARZAJĄCEJ OWOCOWANIE W WARUNKACH BEZGLEBOWYCH NA RYNNACH}

\section{ABSTRAKT}

\section{Cel pracy}

Przemysłowe bezglebowe uprawy roślin są związane z powstawaniem odcieków, które mogą stanowić zagrożenie dla środowiska. Ich zagospodarowanie stanowi ważne zagadnienie ze względu na ograniczenie rozpraszania składników w środowisku, ale również ograniczenie użycia wody, która w tego typu uprawach jest elementem kluczowym nie tylko pod względem ilościowym, ale i jakościowym. 
Kopeć, M., Mierzwa-Hersztek, M., Gondek, K., Zaleski, T., Bogdał, S., Bieniasz, M., Błaszczyk, J., Knaga, J., Nawrocki, J., Pniak, M. (2019). Variability of nutrients in the leachates... Acta Sci. Pol., Formatio Circumiectus, 18 (4), 13-23. DOI:

\section{Materiały i metody}

Na przykładzie plantacji truskawki powtarzającej owocowanie w systemie rynnowym na podłożu bezglebowym przeanalizowano zmienność składników w odciekach.

\section{Wyniki i wnioski}

Skład chemiczny odcieków charakteryzowała zmienność zawartości pierwiastków (składników pokarmowych) w okresie wegetacji. Zmiany te są spowodowane ilością podawanych składników w pożywce i częstotliwością fertygacji uwarunkowaną transpiracją i ilością biomasy roślin warunkującą ilości pobieranych składników. Pod względem chemicznym ponowne wykorzystanie odcieków z plantacji truskawki w procesie odzysku nie jest wykluczone.

Słowa kluczowe: odcieki, składniki, truskawka powtarzająca owocowanie 